Published December 2019

EKONOMIKAWAN : Jurnal IImu Ekonomi dan Studi Pembangunan

ISSN : 1693-7600 (Print), ISSN : 2598-0157 (Online), http://jurnal.umsu.ac.id/indexphp/skawan

\title{
Pemberdayaan Masyarakat Desa Padangsambian Kaja dalam Pemenuhan Kewajiban Pajak Desa
}

\author{
A. Ragil Kuncoro \\ Politeknik Keuangan Negara STAN \\ Jl. Bintaro Utama Sektor V Bintaro Jaya, Tangerang Selatan 15222 \\ e-mail :ant_ragil_kun@pknstan.ac.id
}

\begin{abstract}
ABSTRAK
Salah satu permasalahan yang dihadapi Desa Padangsambian Kaja adalah pemenuhan kewajiban perpajakan yang belum sesuai dengan ketentuan perundang-undangan yang berlaku. Permasalahan ini disebabkan oleh pengetahuan perpajakan para aparatur pemerintah masih rendah. Guna mengatasi permasalahan tersebut, tim 5 Kuliah Kerja Mahasiswa Politeknik Keuangan Negara STAN melaksanakan program pengabdian masyarakat yang bertujuan meningkatkan kapasitas sumber daya manusia. Program pengabdian masyarakat dilakukan dengan pendekatan asset-based community development atau pemberdayaan masyarakat berbasis pada aset, berfokus pada human capital, yaitu keahlian, keterampilan dan pengetahuan orang-orang yang terlibat di dalamnya. Dengan pendekatan ini, program pemberdayaan disusun melalui 4 (empat) proses yang berkesinambungan, yaitu community organizing, evaluation \& implementation, planning dan visioning. Selanjutnya penerapan metode diwujudnyatakan dalam program pelatihan dan pendampingan masyarakat dalam memenuhi kewajiban perpajakan. Hasil yang diharapkan adalah peningkatan keahlian, keterampilan dan pengetahuan masyarakat untuk melaksanakan kewajiban perpajakan secara benar sesuai dengan peraturan yang berlaku. Luaran yang dapat dilihat adalah aparatur desa sudah mulai melakukan pemotongan dan/atau pemungutan pajak secara lebih baik serta berupaya untuk melaporkan pajak yang telah dipotong ataupun dipungut.
\end{abstract}

Kata kunci: asset-based community development, kewajiban pajak, pajak, pemberdayaan masyarakat 


\title{
Padangsambian Kaja Village Community Empowerment in Fulfilling Village Tax Obligations
}

\begin{abstract}
One of the problems faced by Padangsambian Kaja Village is the fulfillment of tax obligations that have not been in accordance with the regulations. This problem is caused by the tax knowledge of the government apparatus is still low. In order to overcome this problem, the team 5 Kuliah Kerja Mahasiswa Politeknik Keuangan Negara STAN conducted a community service program aimed at increasing the capacity of human resources. Community service programs are carried out using an asset-based community development approach, focusing on human capital, namely the expertise, skills and knowledge of the people involved in it. According to this approach, the empowerment program is structured through 4 (four) continuous processes, namely community organizing, evaluation \& implementation, planning and visioning. Furthermore, the application of the method was manifested in the training program and community assistance in meeting tax obligations. The expected result is an increase in the expertise, skills and knowledge of the community to carry out tax obligations properly in accordance with the regulations. The output that can be seen is that the village apparatus has started to collect taxes better and try to report taxes that have been withheld or collected.
\end{abstract}

Keywords: asset-based community development, community development, tax, tax obligation

\section{PENDAHULUAN}

Peraturan Menteri Dalam Negeri Nomor 20 Tahun 2018 tentang Pengelolaan Keuangan Desa memberikan definisi tentang keuangan desa. Dalam peraturan ini disebutkan bahwa keuangan desa adalah semua hak dan kewajiban desa yang dapat dinilai dengan uang serta segala sesuatu berupa uang dan barang yang berhubungan dengan pelaksanaan hak dan kewajiban desa. Dari pengertian tersebut tersirat ruang lingkup keuangan desa yang cukup luas. Keuangan desa tidak saja berbicara tentang penerimaan/pengeluaran uang untuk desa, namun juga termasuk aspek-aspek administratif yang melingkupinya.

Salah satu aspek yang tidak dapat dipisahkan dari keuangan desa adalah hak dan kewajiban di bidang perpajakan. Desa memiliki hak atas bagi hasil pajak. Hak ini menjadi salah satu sumber penerimaan desa. Di sisi lain, desa memiliki kewajiban perpajakan sebagaimana diamanatkan dalam Pasal 58 Peraturan Menteri Dalam Negeri Nomor 20 Tahun 2018 tentang Pengelolaan Keuangan Desa. Pada Pasal 58 tersebut dinyatakan bahwa setiap pengeluaran kas desa yang menyebabkan beban atas anggaran belanja desa dikenakan pajak sesuai dengan ketentuan peraturan perundangan mengenai perpajakan yang berlaku. 
Sesuai dengan ketentuan peraturan perundangan perpajakan yang berlaku, secara umum sistem perpajakan di Indonesia menggunakan sistem self assessment. Sistem ini menitikberatkan pada partisipasi warga masyarakat untuk secara aktif melaksanakan hak dan kewajiban perpajakannya secara mandiri. Pada sistem ini, masyarakat dituntut untuk tidak sekadar tahu tentang perpajakan, namun juga mampu secara aktif mendaftarkan diri sebagai wajib pajak, menghitung dan memperhitungkan pajak yang terutang, menyetor dan/atau membayar pajak yang terutang serta melaporkan kewajiban perpajakan yang telah dilakukan.

Mengutip pendapat Ariani (2000) dalam Muamarah dan Suyani (2019), pengetahuan perpajakan adalah pengetahuan mengenai konsep ketentuan umum di bidang perpajakan, jenis pajak yang berlaku di Indonesia mulai dari subyek pajak, obyek pajak, tarif pajak, perhitungan pajak terutang, pencatatan pajak terutang, sampai dengan bagaimana pengisian formulir pelaporan pajak. Dari itu dapat dibayangkan betapa kompleksnya pemenuhan kewajiban perpajakan terkait dengan keuangan desa. Lebih lanjut, Nur Hidayati (2008) dalam Muamarah dan Suyani (2019) memberikan indikator pengetahuan perpajakan yang meliputi:

1. Pengetahuan mengenai batas waktu pembayaran dan pelaporan.

2. Pengetahuan mengenai ketentuan umum dan tata cara perpajakan.

3. Pengetahuan mengenai sistem perpajakan.

Kompleksitas pemenuhan kewajiban perpajakan yang dihadapi aparatur desa tersebut diduga menimbulkan persoalan tersendiri. Muara dari persoalan ini akan berdampak pada rendahnya kepatuhan pajak bendahara desa dan tersendatnya pembayaran ataupun penyetoran pajak terkait dengan belanja desa. Dengan pertimbangan tersebut maka penulis dan tim 5 Kuliah Kerja Mahasiswa Politeknik Keuangan Negara STAN melakukan program pengabdian kepada masyarakat untuk meningkatkan pemberdayaan masyarakat dalam pemenuhan kewajiban pajak desa. Desa yang menjadi obyek pengabdian masyarakat adalah Desa Padangsambian Kaja, salah satu desa yang berada di wilayah kecamatan Denpasar Barat, Kota Denpasar, Provinsi Bali.

\section{KAJIAN TEORI}

\section{Pemberdayaan Masyarakat}

Pemberdayaan masyarakat (community development) menurut para ahli masih memiliki pengertian yang belum seragam. Pendapat Long (1975) dalam Mattessich dan Monsey (2004) yang dikutip Haines (2009) menyebutkan bahwa pemberdayaan masyarakat merupakan suatu proses pendidikan untuk memampukan warga masyarakat mengidentifikasi persoalan yang mereka hadapi. Sementara Ferguson dan Dickens (1999) menyebut pemberdayaan masyarakat adalah pembangunan aset yang meningkatkan kualitas hidup para penduduk berpenghasilan rendah atau menengah dalam lingkungannya. Haines (2007) mendefinisikan pemberdayaan masyarakat sebagai upaya-upaya terencana untuk menghasilkan aset guna meningkatkan kapasitas penduduk dalam memperbaiki kualitas hidup mereka. Berbagai definisi tersebut secara garis besar menunjukkan adanya suatu proses dan adanya capaian yang dikehendaki. Unsur yang kental dalam pemberdayaan masyarakat adalah mengajarkan sesuatu kepada warga masyarakat untuk memecahkan persoalan-persoalan mereka sehingga kualitas hidup mereka menjadi lebih baik. 
Salah satu pendekatan dalam pemberdayaan masyarakat adalah menggunakan pendekatan aset (asset-based community development). Pendekatan ini berfokus pada peningkatan kapasitas modal yang ada di masyarakat tersebut, seburuk apapun modal yang ada. Green dan Haines (2002) menyebut modal yang ada di masyarakat setidaknya mencakup modal sumber daya manusia (human capital), modal fisik (physical capital), modal finansial (financial capital) dan modal lingkungan (environmental capital).

Modal sumber daya manusia didefinisikan sebagai bakat, keahlian dan pengetahuan anggota komunitas. Adapun modal fisik merupakan semua benda berwujud baik berupa jalan, bangunan maupun insfrastruktur yang ada pada komunitas. Modal finansial adalah modal berupa uang untuk pendanaan yang bisa bersumber dari modal sendiri maupun pinjaman yang ada pada komunitas. Sedangkan modal lingkungan adalah sumberdaya alam termasuk di dalamnya cuaca, musim maupun potensi rekreasi atau daerah wisata.

Dalam pendekatan asset-based, pemberdayaan masyarakat berfokus pada pendidikan dan partisipasi anggota masyarakat untuk mengelola aset mereka. Adapun proses yang melingkupi pada pendekatan ini meliputi proses-proses pengorganisasian komunitas, implementasi dan evaluasi, perencanaan dan penetapan visi. Proses-proses ini tidak selalu harus berada pada tahap yang berurutan ataupun bersamaan, namun disesuaikan dengan kebutuhan pengguna.

Pendekatan asset-based community development digambarkan sebagaimana dalam gambar 1.

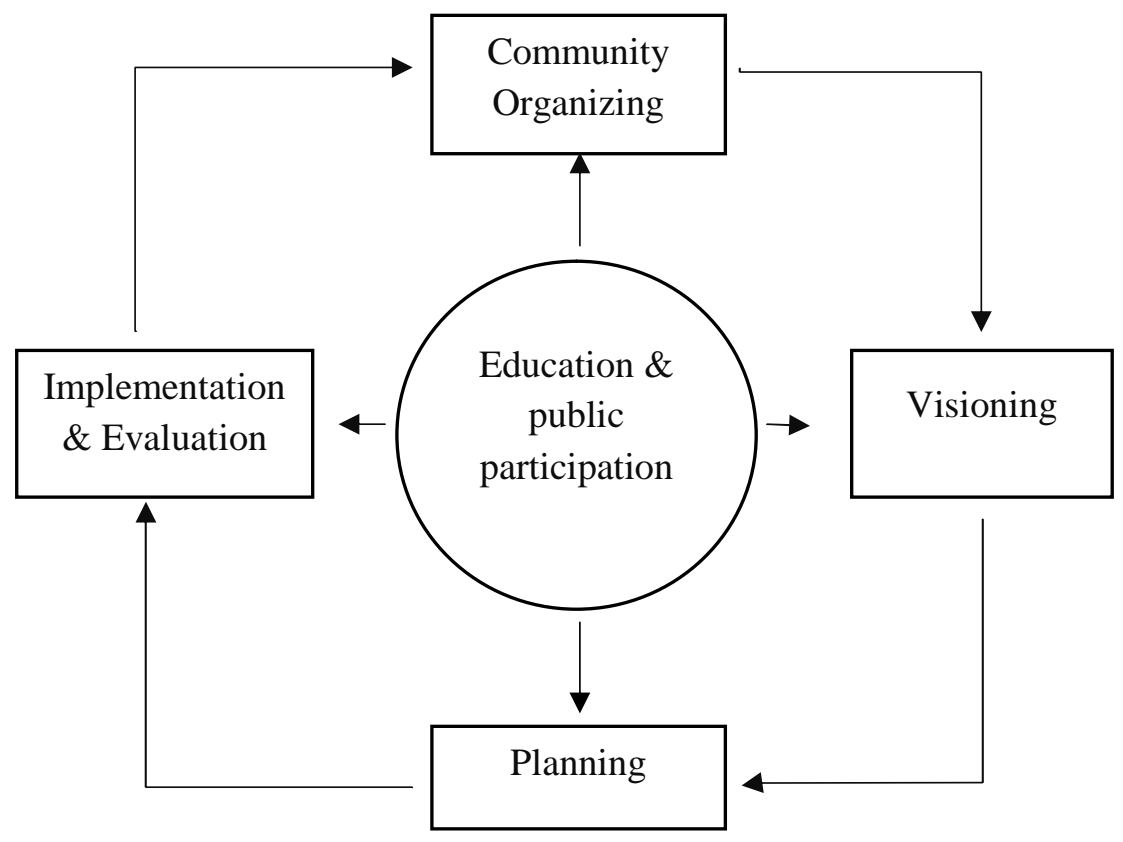

Gambar 1. Asset-based community development process (Haines, 2009) 


\section{Kewajiban Pajak Desa}

Kewajiban pajak desa yang dimaksud di sini adalah kewajiban pemerintah desa untuk menjalankan ketentuan peraturan perundangan. Kewajiban ini secara eksplisit termuat dalam Peraturan Menteri Dalam Negeri Nomor 20 Tahun 2018 tentang Pengelolaan Keuangan Desa. Dalam Pasal 58 jelas dinyatakan bahwa:

1) Setiap pengeluaran kas Desa yang menyebabkan beban atas anggaran Belanja Desa dikenakan pajak sesuai dengan ketentuan peraturan perundangan mengenai perpajakan yang berlaku.

2) Kaur Keuangan sebagai wajib pungut pajak melakukan pemotongan pajak terhadap pengeluaran kas Desa sebagaimana dimaksud pada ayat (1).

3) Pemotongan pajak sebagaimana dimaksud pada ayat (2) meliputi pengeluaran kas Desa atas beban belanja pegawai, barang/jasa, dan modal.

4) Kaur Keuangan wajib menyetorkan seluruh penerimaan pajak yang dipungut sesuai dengan ketentuan peraturan perundang-undangan.

Secara umum kewajiban pajak desa meliputi pemotongan dan/atau pemungutan pajak serta menyetorkan pajak-pajak yang telah dipotong atau dipungut tersebut. Secara ringkas, pajak yang tercakup adalah:

- Pajak Penghasilan Pasal 21 yaitu pajak atas pembayaran berupa gaji, upah, honorarium, dan pembayaran lain yang diterima oleh Orang Pribadi (OP);

- Pajak Penghasilan Pasal 22 yaitu pajak pajak dari Pengusaha/Toko terkait dengan pembayaran atas pembelian barang dengan nilai pembelian di atas Rp 2.000.000,tidak terpecah-pecah;

- Pajak Penghasilan Pasal 23, yaitu pajak dari penghasilan yang diterima rekanan atas sewa (tidak termasuk sewa tanah dan atau bangunan), serta imbalan jasa manajemen, jasa teknik, jasa konsultan dan jasa lain;

- Pajak Penghasilan Pasal 4 ayat 2, yaitu pajak atas pembayaran pengalihan hak atas tanah dan atau bangunan, persewaan tanah dan atau bangunan, dan jasa konstruksi;

- Pajak Pertambahan Nilai atau PPN, yaitu pajak atas pembelian barang atau pemanfataan Jasa Kena Pajak yang jumlahnya di atas Rp 1.000.000,- tidak merupakan pembayaran yang terpecah-pecah.

\section{Badan Usaha Milik Desa}

Badan Usaha Milik Desa atau biasa dikenal juga dengan BUM Desa adalah badan usaha yang seluruh atau sebagian besar modalnya dimiliki oleh desa melalui penyertaan secara langsung yang berasal dari kekayaan desa yang dipisahkan guna mengelola aset, jasa pelayanan, dan usaha lainnya untuk sebesar-besarnya kesejahteraan masyarakat desa. Pengertian ini termuat dalam Undang-undang Nomor 6 Tahun 2014 tentang Desa.

Pendirian BUM Desa dimaksudkan untuk melaksanakan tugas desa dalam menyelenggarakan cabang-cabang produksi yang penting bagi desa dan yang menguasai hajat hidup orang banyak dengan semangat kekeluargaan dan kegotong-royongan. Dengan demikian diharapkan BUM Desa mampu meningkatkan kemampuan masyarakat desa dalam mengendalikan perekonomian di desa untuk sebesar-besar kesejahteraan masyarakat sehingga tercipta kemandirian ekonomi di tingkat desa. 


\section{METODE}

Untuk mencapai tujuan pemberdayaan masyarakat dalam pemenuhan kewajiban pajak desa, pengabdian masyarakat di Desa Padangsambian Kaja dilakukan secara bertahap sesuai dengan pendekatan asset-based community development. Fokus yang diambil pada pendekatan ini adalah pengembangan kapasitas sumber daya manusia (human capital) yang diharapkan bermuara pada peningkatan keahlian, keterampilan dan pengetahuan manusia.

Tahap pertama yang dilakukan dalam pemberdayaan masyarakat berbasis aset adalah pengorganisasian komunitas. Sesuai dengan istilahnya, kegiatan ini dilakukan dengan menggerakkan para perangkat desa untuk mengidentifikasi permasalahan yang dihadapi terkait dengan pemenuhan kewajiban pajak desa. Pada tahap ini, tim pengabdian masyarakat melakukan wawancara pendahuluan serta meninjau hasil kerja yang sedang berjalan agar dapat mengidentifikasi permasalahan yang ada di desa tujuan pengabdian masyarakat. Selain mengidentifikasi masalah, tujuan dari pengorganisasian komunitas adalah juga memantik kesadaran para pihak yang terlibat dalam pemenuhan kewajiban perpajakan di desa tujuan.

Tahap selanjutnya adalah evaluasi atas implementasi pemenuhan kewajiban perpajakan yang sudah pernah dilakukan. Pada tahap ini tim melakukan wawancara dengan pihak desa untuk mengidentifikasi sumber daya yang ada termasuk di dalamnya kelemahan dan kekurangan, maupun potensi dan kelebihan yang dimiliki perangkat desa untuk memecahkan permasalahan dalam pemenuhan kewajiban perpajakan. Hasil evaluasi dan identifikasi permasalahan selanjutnya digunakan sebagai bahan pertimbangan dalam membuat perencanaan pelatihan dan pendampingan yang dibutuhkan.

Tahap selanjutnya merencanakan dan melakukan kegiatan-kegiatan untuk pencapaian visi, dalam hal ini memberikan edukasi serta mendorong partisipasi anggota komunitas. Dalam tahap ini tim Kuliah Kerja Mahasiswa menyusun program pelatihan dan pendampingan pemenuhan kewajiban pajak desa. Program pelatihan dan pendampingan dilakukan selama 5 (lima) hari kerja bertempat di kantor Kepala Desa Padangsambian Kaja, Denpasar.

\section{HASIL DAN PEMBAHASAN}

Desa Padangsambian Kaja merupakan salah satu desa yang berada di wilayah kecamatan Denpasar Barat, Kota Denpasar, Provinsi Bali. Desa ini secara resmi berdiri sejak 1 Juni 1982. Sebelum itu, Padangsambian Kaja merupakan bagian dari Kelurahan Padangsambian. Berdasarkan Surat Keputusan Gubernur Nomor 157 Tahun 1982, Padangsambian Kaja secara resmi terpisah dari Kelurahan Padangsambian dan berdiri sebagai sebuah desa baru.

Secara geografis, desa Padangsambian Kaja terletak di daerah perbatasan Kota Denpasar dengan Kabupaten Badung. Luas wilayah secara keseluruhan kurang lebih 409 hektar dengan batas-batas wilayah Kelurahan Sempidi Kabupaten Badung di sebelah utara, Kelurahan Padangsambian di sebelah selatan, Desa Ubung Kaja dan Kelurahan Ubung di sebelah timur dan Desa Dalung dan Kelurahan Kerobokan Kaja di sebelah Barat. Desa ini membawahi 9 (sembilan) dusun yang terletak pada 115.1899 BT / -8.652808 LS. Bentang alam Desa Padangsambian Kaja sebagian besar merupakan wilayah permukiman penduduk dengan beberapa wilayah masih terdapat sawah, tegalan, kebun, kawasan usaha dan pergudangan. 
Secara demografis, penduduk desa Padangsambian Kaja sampai dengan tahun 2016 berjumlah 18.655 jiwa terdiri dari 9.377 laki-laki dan 9.278 perempuan. Saat ini desa Padangsambian Kaja mengelola Badan Usaha Milik Desa (BUM Desa) Bhuwana Sari Jaya. BUM Desa Bhuwana Sari Jaya didirikan berdasarkan Peraturan Desa Padangsambian Kaja Nomor 7 Tahun 2017 tentang Pendirian, Pengurusan dan Pengelolaan, dan Pembubaran Badan Usaha Milik Desa yang diundangkan tanggal 14 Desember 2017 pada Lembaran Desa Padangsambian Kaja Tahun 2017 Nomor 7. Tujuan didirikannya BUM Desa Bhuwana Sari Jaya adalah:

1. Meningkatkan perekonomian desa;

2. Mengoptimalkan aset desa agar bermanfaat untuk kesejahteraan desa;

3. Meningkatkan usaha masyarakat dalam pengelolaan potensi ekonomi desa;

4. Mengembangkan rencana kerjasama usaha antar desa dan/atau pihak ketiga;

5. Menciptakan peluang dan jaringan pasar yang mendukung kebutuhan layanan umum warga;

6. Membuka lapangan pekerjaan;

7. Meningkatkan kesejahteraan masyarakat melalui perbaikan pelayanan umum, pertumbuhan dan pemerataan ekonomi desa;

8. Meningkatkan pendapatan masyarakat dan Pendapatan Asli Desa;

9. Diharapkan keberadaan BUM Desa Bhuwana Sari Jaya dapat menjadi sentra perkembangan ekonomi Desa Padangsambian Kaja.

BUM Desa Bhuwana Sari Jaya memulai kegiatan operasional secara resmi pada 1 Maret 2018 dengan membuka Unit Usaha Perdagangan berupa toko yang menyediakan sembako, gas bersubsidi, layanan pembayaran rekening listrik, telepon dan PDAM, layanan samsat, penyediaan makanan dan minuman serta pengadaan barang dan jasa untuk Pemerintah Desa. Selain itu BUM Desa Bhuwana Sari Jaya juga membuka Unit Usaha Jasa Swakelola Sampah berupa layanan pengangkutan sampah dari rumah/tempat usaha warga ke Tempat Penampungan Sampah Sementara (TPSS) di Desa Padangsambian Kaja.

Pemerintah Desa Padangsambian Kaja pada Tahun Anggaran 2018 telah menyertakan modal sejumlah lebih dari Rp. 600.000.000,- serta 9 (sembilan) unit Motor Cikar untuk digunakan sebagai modal usaha oleh BUM Desa Bhuwana Sari Jaya.

Sesuai dengan sasaran pengabdian masyarakat yang ditetapkan, maka tim melakukan wawancara, peninjauan di lapangan dan evaluasi atas kewajiban perpajakan Desa Padangsambian Kaja dan BUM Desa Bhuwana Sari Jaya. Hasil evaluasi dan wawancara mengerucut pada identifikasi permasalahan yang ada pada Desa Padangsambian Kaja. Permasalahan tersebut adalah:

1. Kurang optimalnya fungsi bendahara dan staff keuangan dalam mengklasifikasikan, memotong serta memungut pajak atas setiap transaksi barang dan/atau jasa disebabkan oleh minimnya pengetahuan bendahara mengenai peraturan perpajakan.

2. Pengetahuan pengurus Badan Usaha Milik Desa (BUM Desa) terkait perpajakan BUM Desa masih minim, hal ini disebabkan oleh kurangnya jumlah dan kapasitas SDM pengelola serta peraturan terkait pendirian, pengelolaan dan pengusahaan BUM Desa yang masih tergolong baru sehingga membutuhkan sosialisasi tata cara pembukuan berikut dengan pemenuhan hak dan kewajiban perpajakan BUMDesa atas laba usaha dan transaksi yang dilakukan. 
Berdasarkan pada identifikasi masalah tersebut, maka tim KKM merencanakan kegiatan pelatihan dan pendampingan untuk perangkat desa yang terlibat dalam pengelolaan keuangan desa pada umumnya, dan pemenuhan kewajiban pajak pada khususnya. Program pelatihan dan pendampingan dilaksanakan dalam waktu 5 (lima) hari kerja dengan mengundang para pejabat yang memiliki tugas dan fungsi terkait dengan keuangan desa. Pelatihan dan pendampingan dilaksanakan di Kantor Desa Padangsambian Kaja. Adapun topik pelatihan dan pendampingan sebagaimana tertuang dalam Tabel 1.

Tabel 1. Matrik kegiatan pelatihan dan pendampingan Desa Padangsambian Kaja

\begin{tabular}{|c|c|c|}
\hline Hari & Kegiatan & Deskripsi Kegiatan \\
\hline 1 & Akuntabilitas Desa & $\begin{array}{l}\text { Memberikan pengetahuan dasar terkait } \\
\text { akuntabilitas desa dan pelaporan keuangan desa. }\end{array}$ \\
\hline 2. & $\begin{array}{l}\text { Inventarisasi, } \\
\text { Penilaian Aset serta } \\
\text { Pajak Desa }\end{array}$ & $\begin{array}{l}\text { Memberikan pengetahuan terkait aspek hak dan } \\
\text { kewajiban perpajakan Bendahara Desa, dan } \\
\text { Akuntansi Perpajakan Desa. }\end{array}$ \\
\hline 3. & $\begin{array}{l}\text { Inventarisasi, } \\
\text { Penilaian Aset serta } \\
\text { Pajak BUM Desa }\end{array}$ & $\begin{array}{l}\text { Memberikan pengetahuan terkait aspek hak dan } \\
\text { kewajiban perpajakan BUMDesa. }\end{array}$ \\
\hline 4. & $\begin{array}{l}\text { Akuntansi } \\
\text { Desa }\end{array}$ & $\begin{array}{l}\text { Memberikan pengetahuan terkait akuntabilitas } \\
\text { BUMDesa dan pelaporan keuangan (akuntansi) } \\
\text { BUMDesa. }\end{array}$ \\
\hline 5. & $\begin{array}{l}\text { Pendampingan, } \\
\text { problem solving } \\
\text { dan supervisi }\end{array}$ & $\begin{array}{l}\text { Usulan dan Saran terkait permasalahan } \\
\text { implementasi Akuntabilitas Desa, Akuntansi } \\
\text { BUMDesa, Perpajakan Desa dan BUMDesa. }\end{array}$ \\
\hline
\end{tabular}

Sumber: diolah Penulis

Pada pelatihan hari pertama, materi yang disampaikan secara keseluruhan ialah tentang Transfer ke Daerah dan Dana Desa dengan Dana Desa sebagai fokus utama. Kegiatan diawali dengan pembukaan dari koordinator tim KKM dilanjutkan dengan pembukaan dari dosen pembimbing dan Kepala Desa setempat. Kemudian memulai sosialisasi dalam bentuk pemaparan materi yang berisi tentang penjelasan Dana Desa antara lain seperti jenis-jenis Dana Transfer ke Daerah dan Dana Desa, tujuan, perbandingan dana desa tiap tahun, kebijakan umum dana desa, pengalokasian dana desa, penyaluran dana desa, dan pengawasan dana desa. Desa Padangsambian Kaja telah menggunakan Aplikasi Sistem Keuangan Desa (SISKEUDES) dalam hal memasukkan data, mengolah dan melaporkan data transaksinya. 


\section{Published December 2019}

EKONOMIKAWAN : Jurnal IImu Ekonomi dan Studi Pembangunan

ISSN : $1693-7600$ (Print), ISSN : 2598-0157 (Online), http://jurnal.umsu.ac.id/indexphplekawan

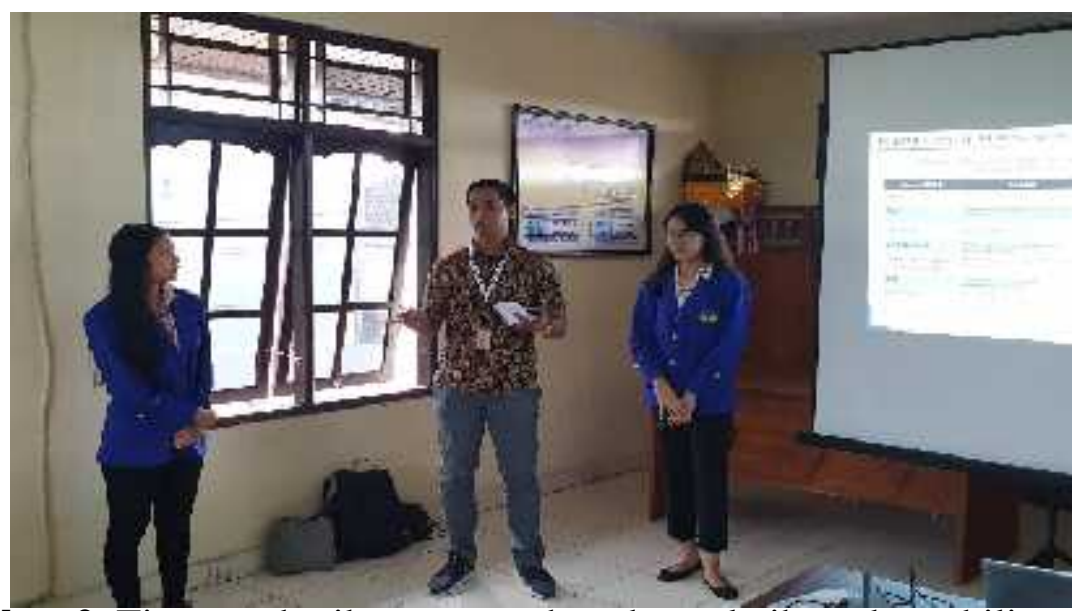

Gambar 2. Tim memberikan pengarahan dan pelatihan akuntabilitas desa

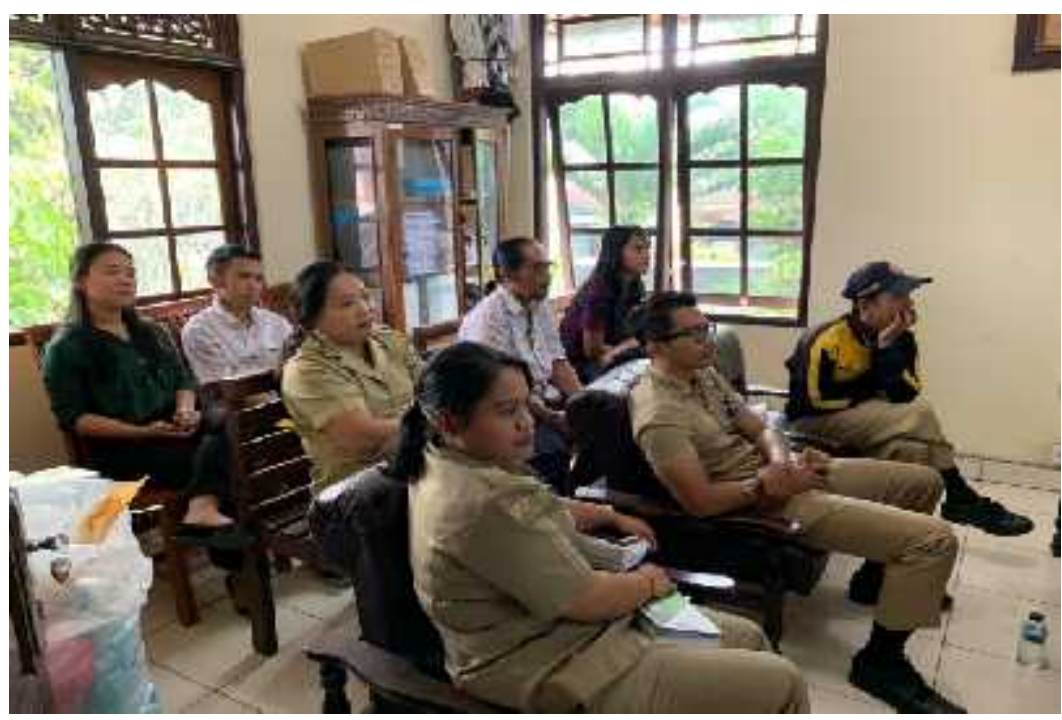

Gambar 3. Para peserta pelatihan akuntabilitas desa

Sesi selanjutnya adalah supervisi dan tanya jawab untuk mengeksplorasi lebih jauh permasalahan yang ada di Desa Padangsambian Kaja. Pada sesi ini ditemukan permasalahan yaitu terdapat perbedaan ketentuan prioritas penggunaan Dana Desa untuk pemberdayaan dan pembangunan berdasarkan Peraturan Presiden Nomor 60 Tahun 2014 tentang Dana Desa yang Bersumber dari APBN dengan penetapan prioritas penggunaan dana desa untuk kegiatan warga yang termasuk dalam bidang pembinaan masyarakat sebagaimana tercantum pada Permendes No. 16 tahun 2018 tentang Prioritas Penggunaan Dana Desa. Selain itu, perangkat desa merasa bahwa sistem siskeudes yang baru cenderung lebih rumit dibandingkan versi lama. Dampaknya, perangkat desa harus melakukan 2 kali input, secara online maupun offline untuk laporan yang akan diserahkan ke pemerintah kota setempat, yaitu melalui siskeudes dan laporan tertulis manual. 


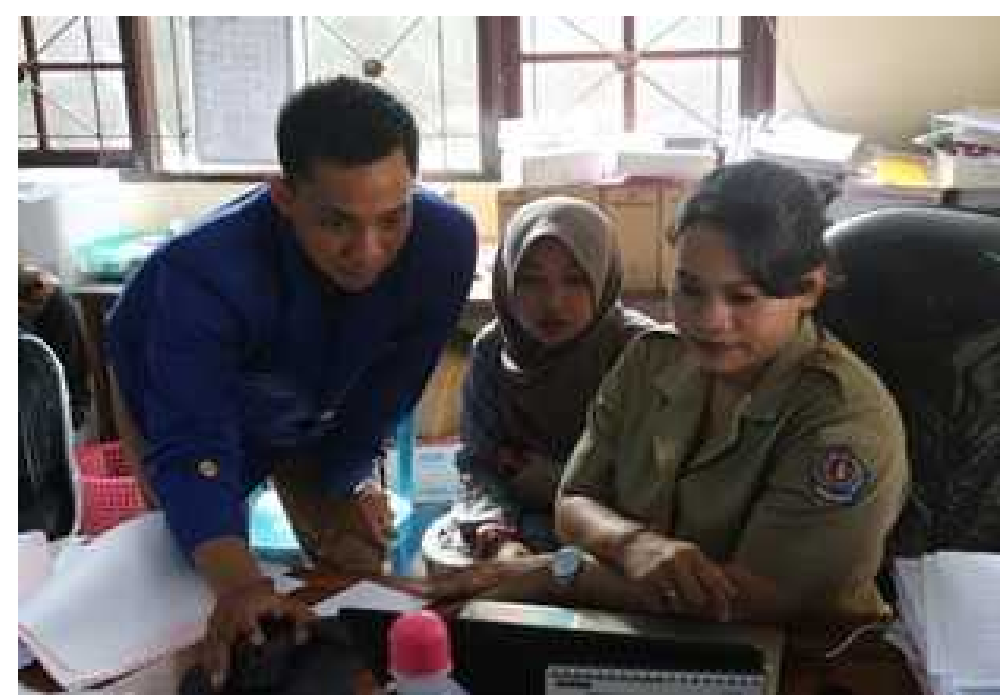

Gambar 4. Tim mendampingi pelatihan pajak desa

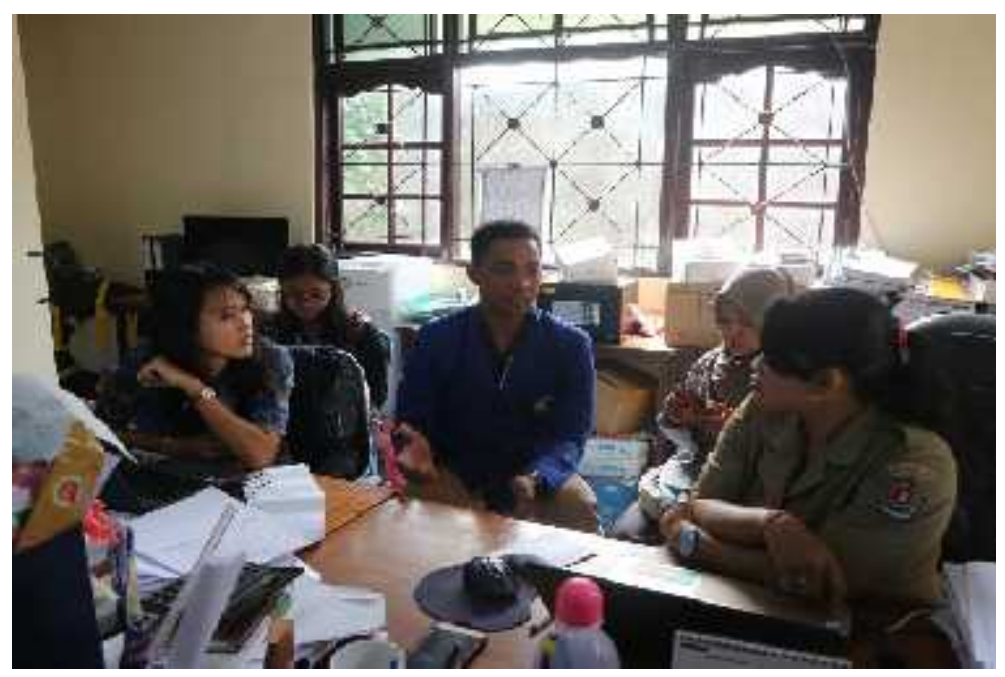

Gambar 5. Tim memberikan pelatihan pajak desa

Ketiga permasalahan tersebut berada di luar jangkauan tim KKM. Meski demikian, sebagai saran perlu diadakan sinkronisasi dan harmonisasi kebijakan pada level kementerian/lembaga yang membidangi urusan dana desa dan pemerintahan desa agar mampu memberikan kemudahan dan kepastian hukum di dalam pengelolaan dana desa pada level teknis di lapangan. Diperlukan suatu sistem informasi yang terintegrasi di mana semua keperluan administrasi pengelolaan dana desa dapat terselesaikan dalam satu kali input.

Pada hari kedua dilaksanakan pelatihan perpajakan untuk desa. Adapun tujuan dari kegiatan ini adalah untuk mengetahui sejauh mana pemahaman bendahara dan staf keuangan Kantor Desa Padangsambian Kaja mengenai kewajiban perpajakannya serta memberikan pengetahuan mengenai hak dan kewajiban perpajakan yang dimiliki oleh bendahara. 


\section{Published December 2019}

EKONOMIKAWAN : Jumal IImu Ekonomi dan Studi Pembangunan

ISSN : $1693-7600$ (Print), ISSN : 2598-0157 (Online), http://jurnal.umsu.ac.id/indexphplekawan

Selama kegiatan berlangsung terdapat pertanyaan yang diajukan oleh bendahara mengenai kewajiban perpajakan atas kegiatan yang dilakukan oleh Kantor Desa seperti pemberian hadiah, penyewaan kios, pemotongan pajak atas pembelian tertentu, pemotongan pajak atas upah, pemotongan pajak atas jasa, dan kegiatan lainnya. Pengenaan pajak yang dilakukan oleh bendahara secara umum sudah benar, namun masih terdapat beberapa kekurangan yaitu bendahara belum mengenakan Pajak Pertambahan Nilai (PPN) atas beberapa kegiatan yang seharusnya dikenakan PPN, kurangnya pengetahuan bendahara mengenai peraturan perpajakan yang berlaku, serta adanya kesulitan dalam membedakan mekanisme pemotongan dan pemungutan pajak, siapa pihak yang memotong dan memungut, dan belum terpenuhinya kewajiban pelaporan SPT Masa oleh bendahara. Tim KKM kemudian memberi sosialisasi mengenai peraturan-peraturan perpajakan yang harus diketahui oleh bendahara, memberikan jawaban atas pertanyaan yang diajukan, serta memberi saran agar bendahara tidak perlu ragu untuk mendatangi kantor pajak untuk berkonsultasi mengenai hak dan kewajiban perpajakannya.

Pada hari ketiga, pelatihan difokuskan pada aspek perpajakan Badan Usaha Milik Desa. Sebagaimana diidentifikasi pada tahap pengorganisasian komunitas diketahui bahwa pengetahuan pengurus Badan Usaha Milik Desa (BUM Desa) terkait perpajakan BUM Desa masih minim. Hal ini disebabkan oleh kurangnya jumlah dan kapasitas SDM pengelola. Di sisi lain peraturan terkait pendirian, pengelolaan dan pengusahaan BUM Desa masih tergolong baru sehingga membutuhkan sosialisasi tata cara pembukuan berikut dengan pemenuhan hak dan kewajiban perpajakan BUMDesa atas laba usaha dan transaksi yang dilakukan.

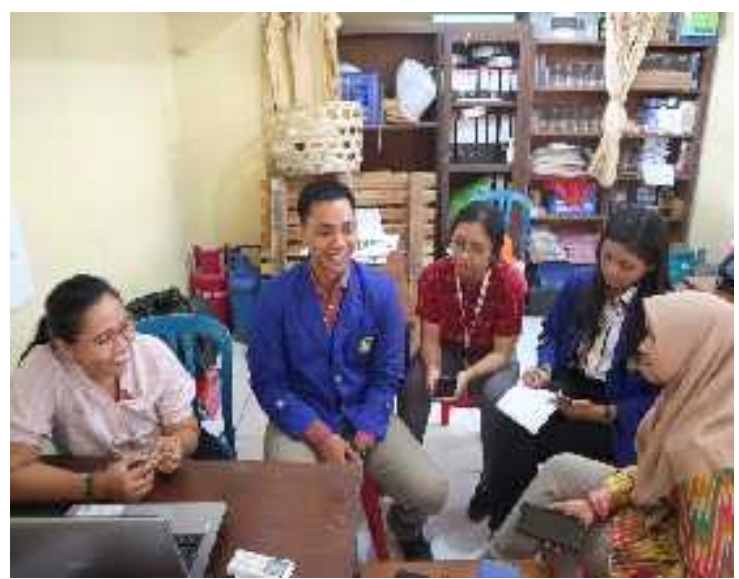

Gambar 6. Tim memberikan pelatihan pajak BUM Desa

Sosialisasi dan tanya jawab dilakukan untuk mencoba memecahkan masalah yang dihadapi. Secara umum perangkat desa memiliki rasa ingin tahu yang tinggi dan antusias untuk melaksanakan kewajiban perpajakan. Meski demikian, terdapat satu masalah yang cukup mendasar sehingga menyebabkan aparat desa ragu-ragu untuk menjalankan kewajiban pajak BUM Desa. Permasalahan baru yang ditemukan tersebut adalah kurangnya pemahaman pengurus BUM Desa Bhuwana Sari Jaya terkait jenis badan hukum BUM Desa dan juga kurangnya pemahaman pengurus BUM Desa Bhuwana Sari Jaya terkait kewajiban perpajakan BUMDesa. 
Badan Usaha Milik Desa Bhuwana Sari Jaya sudah memiliki NPWP, namun demikian BUM Desa ini belum memiliki bentuk badan hukum secara resmi sesuai dengan peraturan yang berlaku. Pengurus Badan Usaha Milik Desa Bhuwana Sari Jaya masih berkonsultasi dengan pegawai pajak terkait penentuan badan hukum yang sesuai untuk BUM Desa apakah menggunakan Perseroan Terbatas (PT), koperasi, atau badan hukum lainnya. Setelah menentukan badan hukum yang sesuai, disarankan agar BUM Desa mengukuhkan diri sebagai Pengusaha Kena Pajak agar dapat memungut dan melaporkan PPN/PPnBM yang terutang. Dengan menjadi Pengusaha Kena Pajak, BUM desa juga berhak melakukan pengkreditan Pajak Masukan atas perolehan Barang Kena Pajak, Jasa Kena Pajak, dan berhak meminta restitusi atau kompensasi apabila Pajak Masukan lebih besar daripada Pajak Keluaran.

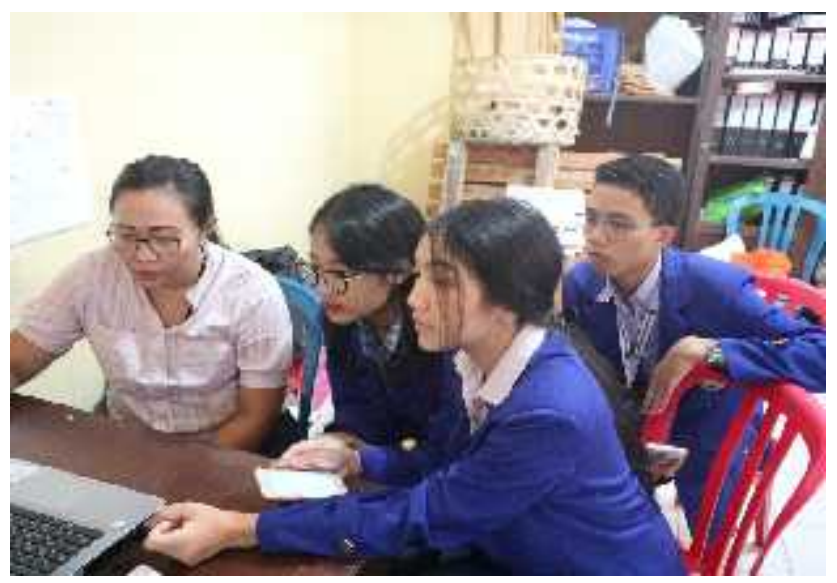

Gambar 7. Tim memberikan pendampingan pajak BUM Desa

Pada hari keempat diadakan pelatihan akuntansi BUM Desa. Pelatihan ini penting untuk memahami pendapatan dan biaya yang terkait dengan keperluan pemajakan. Secara umum akuntansi yang diterapkan di BUM Desa Bhuwana Sari Jaya hanya mengikuti prinsip dan ketentuan yang terdapat dalam aplikasi sistem informasi akuntansi (SIA) BUM Desa. Pada kenyataannya, aplikasi ini berbeda dari tahun ke tahun. Perbedaan ini dirasa menyulitkan petugas yang menggunakan aplikasi. Sebagai contoh, input transaksi ke aplikasi SIA BUM Desa versi 2019 sulit dilakukan karena harus menggunakan nomor akun (kode), sehingga harus tahu nomor akun suatu nama akun atas transaksi yang akan dimasukkan. Akibatnya terjadi keterlambatan atas penyampaian laporan keuangan BUM Desa yang seharusnya disampaikan per semester.

Karena permasalahan berada di luar jangkauan tim KKM, maka tim menyarankan agar Desa Padangsambian Kaja menentukan bentuk badan hukum yang tepat bagi BUM Desa. Hal ini penting untuk kepentingan akuntansi dan pemenuhan kewajiban perpajakan. Kemudian para aparat disarankan untuk mengikuti pelatihan atau bimbingan teknis mengenai penggunaan aplikasi SIA BUM Desa yang terbaru serta mengikuti programprogram pembinaan dan pendalaman materi terkait pertanggungjawaban atas pelaporan keuangan BUM Desa. 


\section{Published December 2019}

EKONOMIKAWAN : Jurnal IImu Ekonomi dan Studi Pembangunan

ISSN : 1693-7600 (Print), ISSN : 2598-0157 (Online), http://jurnal.umsu.ac.id/indexphp/ekawan

Pada hari terakhir pengabdian masyarakat dilakukan dengan melakukan supervisi dan asistensi problem solving. Harus dipahami bahwa kewajiban perpajakan sangat dipengaruhi oleh prosedur akuntansi dan bentuk badan usaha. Permasalahan-permasalahan teknis yang bisa diselesaikan pada saat itu, oleh tim KKM diberikan solusinya. Namun untuk permasalahan yang di luar jangkauan tim, diangkat ke publik agar menjadi perhatian bersama. Sebagai contoh kasus adalah bentuk badan hukum bagi BUM Desa. Sejauh ini desa Padangsambian Kaja belum menentukan bentuk badan hukum bagi BUM Desa mengingat tidak ada ketentuan yang secara tegas mengatur mengenai masalah ini. Dampak dari tidak adanya bentuk badan hukum adalah sulitnya memenuhi ketentuan perpajakan yang berlaku selain menjadi tidak jelas batas-batas antara keuangan desa dengan keuangan badan usaha milik desa.

\section{SIMPULAN}

Pemberdayaan masyarakat merupakan upaya-upaya yang berkesinambungan untuk menumbuhkan daya yang ada di masyarakat dalam memecahkan masalah yang dihadapi guna meningkatkan kualitas hidupnya. Salah satu pendekatan yang digunakan dalam pemberdayaan masyarakat adalah pendekatan asset-based community development atau pemberdayaan masyarakat berbasis pada aset. Pendekatan ini berfokus pada pemberdayaan modal-modal yang ada dalam masyarakat itu.

Salah satu modal yang ada dalam masyarakat adalah sumber daya manusia (human capital). Secara sederhana modal ini adalah keterampilan, keahlian, bakat-bakat dan pengetahuan yang ada pada masyarakat itu. Pemberdayaan masyarakat bisa dilakukan dengan meningkatkan kapasitas human capital.

Kegiatan pengabdian masyarakat di Desa Padangsambian Kaja mencoba menerapkan pendekatan asset-based dalam pemberdayaan masyarakat. Fokus dari pengabdian masyarakat adalah sumber daya manusia yang ada di organisasi desa Padangsambian Kaja untuk mengatasi persoalan mereka yaitu pemenuhan kewajiban perpajakan. Proses pengabdian masyarakat ini berhasil mengidentifikasi berbagai persoalan di Desa Padangsambian Kaja terkait dengan pemenuhan kewajiban perpajakan. Berangkat dari persoalan tersebut, tim pengabdian masyarakat menyusun program pelatihan dan pendampingan bagi aparatur desa.

Harus diakui bahwa investasi dalam sumber daya manusia tidak bisa langsung dinikmati capaiannya. Bahkan semakin digali dan diperdalam, persoalan lain semakin terlihat jelas. Tim pengabdian masyarakat memberikan solusi sesuai dengan kapasitasnya seperti membantu menyiapkan laporan SPT dan menghitung pajak-pajak yang terutang. Namun persoalan yang bersifat kebijakan ataupun perundang-undangan, berada di luar jangkauan tim pengabdian masyarakat. Sejauh ini output yang dihasilkan dari pengabdian masyarakat ini berupa pengetahuan perpajakan yang dimanifestasikan dalam pemenuhan kewajiban pajak tahun berjalan. Saat ini desa Padangsambian Kaja sudah mulai menjalankan kewajiban perpajakannya sesuai dengan ketentuan yang berlaku. Diharapkan pihak-pihak terkait juga terlibat dalam pendampingan desa Padangsambian Kaja agar kepatuhan pajak semakin meningkat. 
Setidaknya terdapat tiga persoalan penting dalam pengelolaan keuangan desa pada umumnya yang mana hal ini berdampak pula pada pemenuhan kewajiban perpajakan. Persoalan pertama adalah aplikasi terkait dengan keuangan desa yang kurang sinkron satu dengan yang lain dan sulit untuk digunakan para perangkat desa. Persoalan kedua adalah kepastian hukum Badan Usaha Milik Desa dan aplikasi SIA yang digunakan. Persoalan ketiga yang paling penting adalah belum adanya sinkronisasi dan harmonisasi antar peraturan pada level kementerian. Persoalan tersebut bisa jadi hanya bersifat kasuistis di Desa Padangsambian Kaja. Meski demikian, Pemerintah diharapkan memberikan jalan keluar atas persoalan yang dihadapi warganya.

\section{DAFTAR PUSTAKA}

Desa Padangsambian Kaja. http://www.desapadangsambiankaja.desa.id.

Direktorat Jenderal Pajak. 2016. Bendahara MahirPajak Edisi Revisi 2016. Jakarta: Tim PenyusunDirektorat Peraturan Perpajakan II.

Haines, Anna., 2009, Asset-Based Community Development, New York: Routledge.

Kementerian Keuangan Republik Indonesia. 2017. Buku Saku Dana Desa: Dana Desa untuk Kesejahteraan Rakyat. Jakarta: Tim Penyusun.

Kementerian Keuangan Republik Indonesia. 2017. Buku Pintar Dana Desa: Dana Desa untuk Kesejahteraan Rakyat. Jakarta: Tim Penyusun.

Mardiasmo. 2011. Perpajakan Edisi Revisi.Yogyakarta: Andi.

Muamarah, Hanik S., dan Suyani, Emik, 2019, Pemajakan Dana Desa, Jurnal KUAT: Keuangan dan Akuntansi Terapan, (Online), Volume 1, No. 2, (http://www.jurnal.pknstan.ac.id, diakses 22Juli 2019).

Peraturan Menteri Dalam Negeri Nomor 20 Tahun 2018 tentang Pengelolaan Keuangan Desa.

Peraturan Menteri Desa, Pembangunan Daerah Tertinggal, dan Transmigrasi Nomor 16 Tahun 2018 tentang Prioritas Penggunaan Dana Desa Tahun 2019.

Peraturan Pemerintah Republik Indonesia Nomor 60 Tahun 2014 Sebagaimana Telah Diubah dengan Peraturan Pemerintah Nomor 22 Tahun 2015 dan Peraturan Pemerintah Nomor 8 Tahun 2016 tentang Dana Desa yang Bersumber dari Anggaran Pendapatan Dan Belanja Negara. 21 Juli 2014. Lembaran Negara Republik Indonesia Tahun 2014 Nomor 168. Jakarta.

Undang-Undang Republik Indonesia Nomor 6 Tahun 2014 tentang Desa. 15 Januari 2014. Lembaran Negara Republik Indonesia Tahun 2014 Nomor 7. Jakarta. 